\title{
STUDENT'S ABILITY AND FACTORS TO USE GERUND AND TO INFINITIVE CASE STUDY: INDONESIAN EFL LEARNERS IN UNIVERSITY LEVEL
}

\author{
Rina Husnaini Febriyanti \\ Program of English Education, Faculty of Language and Art, University of Indraprasta PGRI \\ Jalan Nangka No. 58C Tanjung Barat, Jagakarsa, South Jakarta 12530 \\ rhfebriyanti@gmail.com
}

\begin{abstract}
Mastering grammar seems very challenging for English foreign language learners. Learning grammar constructions that have different system to their first language bring some consequences. One of them is on learning about gerund and to infinitive. The objectives of this study are to describe the ability on mastering gerund and infinitive form and to analyze the factors affecting them to learning its form. This study used descriptive method with the students who took English Structure subject of Indraprasta PGRI University Jakarta as respondents. The data was collected through test and questionnaire, was analyzed, tabulated, calculated and presented in percent form. The research result is the ability of the students on mastering the using of gerund is very poor of $41.82 \%$ respondents have low understanding in gerund. Moreover, mastering the using toinfinitive form is also very poor of $36.36 \%$ respondents have low understanding in to infinitive. The factors were being passive, lack of motivation, slow learning, less practice in doing exercises, poor of literature, and not learning from the mistakes. These findings may encourage the lecturer of English Structure to find out more ways to improve student's ability on using gerund and to infinitive for Indonesian EFL Learners in University level.
\end{abstract}

Key words: student's ability, gerund, to infinitive

\begin{abstract}
ABSTRAK
Penguasaaan tata bahasa menjadi sebuah tantangan bagi pembelajar bahasa Inggris. Mempelajari tata bahasa dengan sistem yang berbeda dengan bahasa pertama menciptakan beberapa konsekuensi. Salah satunya adalah pembelajaran gerund dan to infinitive. Tujuan penelitian yaitu untuk mendeskripsikan kemampuan penguasaan gerund dan to infinitive dan untuk menganalisis faktor yang mempengaruhi pembelajaran tersebut. Penelitian ini menggunakan metode deskriptif dengan responden yaitu mahasiswa English Structure di Universitas Indraprasta PGRI Jakarta. Data dikumpulkan melalui tes dan kuesioner, dianalisis, ditabulasi, dikalkulasi dan disajikan dengan bentuk persentase. Hasil penelitian menunjukkan kemampuan mahasiswa dalam penguasaan penggunaan gerund sangat lemah yaitu $41.82 \%$ responden memiliki pemahaman yang kurang pada penggunaan gerund. Lebih lanjut, penguasaan penggunaan bentuk to infinitive juga lemah yaitu $36.36 \%$ responden kurang memahami penggunaan bentuk to infinitive. Faktor yang mempengaruhi pembelajaran tersebut
\end{abstract}


antara lain sikap pasif dalam belajar, kurangnya motivasi, lambat dalam belajar, kurangnya latihan, kurangnya sumber bacaan, dan tidak belajar dari kesalahan. Temuan-temuan ini membantu dosen English Structure untuk menemukan berbagai cara dalam meningkatkan kemampuan mahasiswa dalam penggunaan gerund dan to infinitive bagi pembelajar bahasa Inggris sebagai bahasa asing di tingkat universitas.

\section{Kata kunci: kemampuan mahasiswa, gerund, to infinitive}

\section{INTRODUCTION}

English in Indonesia is a foreign language. Since it is an international language, as said by Dudeney and Hockly that (2010), one of the interesting things about English as a global language is that it is increasingly being used as a 'lingua franca' (or common language) so that people from non-English-speaking countries can communicate with those who do speak English. For example, at a business meeting in Bangkok, Thailand, with participants from China, Japan, Korea, Thailand and Indonesia, the common language is usually English. Likewise, a business meeting in Munich, Germany, with participants from Sweden, Greece, Italy, Germany and France, usually takes place in English, it is very important to learn it for Indonesian learner. It is learned whether in formal or informal institution. It is commonly taught from primary to high education.

Even though it is learned since primary level, it is still mostly hard to be mastered by Indonesian learner. Besides this language is rarely used by them, there are also several matters that thought as the obstacle on mastering this language. One of the matters is grammar used when English is practiced. Seely says "The word 'grammar' is much abused" (Seely, 2007), and (Harmer, 1997) says "People who learn language encounter a number of problems especially with the grammar of the language can be complicated and which can appear confusing". As stated by Seely and Harmer that it is a crystal-clear that mastering English grammar is not easy especially for Indonesian learner.

Otherwise, learning grammar is very important as a part of mastering English. As told by Penny Ur that "There is no doubt that a knowledge-implicit or explicit-of grammatical rules is essential for mastery of a language; you cannot use words unless you know how they should be put together" (Ur, 2007). Why grammar needs to be taught there are several reasons as told by Thornbury such as "The sentence-machine argument, the fine-tuning argument, the fossilization argument, the advanceorganizer argument, the discrete item argument, the rule-of-law argument, and the learner expectations argument" (Thornbury, 2002). In addition, Dudeney and Hockly (2010) say that lots of people - including many students and those who teach English - think that the grammar is the most important part of a language. And lots of people believe that by learning the grammar, you learn a language. We don't think this is completely true. Instead, we think of grammar as the basic building blocks of a language - when you know grammar, you know things like past tense verbs, how to use conditional forms, how to form questions and so on. But building blocks (the grammar) aren't much use unless you know how to put them together to create a useful object (communicating with others). Even if you know about all the rules in the English language, if you don't know how to apply them when talking to others, this knowledge isn't much use. Inferring by 
the previous arguments it can be said that the understanding of grammar is crucial, yet it will be useless if it is not used in a language function or communication.

There is much diversity compared to Bahasa Indonesia (Indonesian language) such as, tense, in English tense is the core of the language grammar used, while in Bahasa Indonesia it does not use tense; active and passive form, in English is related to the tense pattern that the sentence is active or passive, while in Bahasa Indonesia not; gerund and infinitive, in English there are several verbs are followed by gerund or infinitive, while in Bahasa Indonesia is not and so on. Probably because of the differences of grammar rule between English and Bahasa Indonesa makes Indonesian learners get difficulties on mastering English. This research is focused on describing of gerund and infinitive acquired by the students of Indraprasta PGRI University on the second year. The objectives of this research are: 1) to describe the ability of the students in second year of Indraprasta PGRI University on mastering the using of gerund and infinitive form; and 2) to describe the factors affecting of the students in second year of Indraprasta PGRI University on mastering the using of gerund and infinitive form.

\section{METHOD}

In this research a descriptive method was used to gain the description of the student's ability on mastering gerund and infinitive form and also its factors. The participants on this research were of the students in second year of Indraprasta PGRI University who took the subject of Understanding Structure. The amount of the participants was 55 students who were taken randomly. The instruments of this research were two kinds of instruments they were a test and questionnaires that the pattern of both of them were multiple choices form. The test instrument consists of 15 numbers, and the questionnaire instrument consists of 15 numbers too.

The technique of data analysis process was collecting the data through the instruments which were analyzed by using a descriptive analysis. The data were collected through the tests such as test instrument and questionnaire instrument, afterwards they were tabulated and calculated using Microsoft Excels 2010, and finally they were presented in percent result. The data calculations were enclosed on appendixes page.

The test instrument about gerund and to- infinitive were based on (Azar, 2009) . To find out the mean of the data this study using the formula that was cited from (Arham, 2016) as follows:

Note:

$$
x=\frac{\sum x}{N}
$$

$x \quad:$ The Mean Score

$\sum x \quad$ : The Total Score of Students

$N \quad$ : The Number of Students

In order to know the students ability in using English gerund and infinitive in this research, the writer classified the result of the research based on the following scores:

96-100 is classified as excellent

86-95 is classified as very good

76-85 is classified as good

66-75 is classified as fairly good

56-65 is classified as fair

46-55 is classified as poor

0- 45 is classified as very poor

The data collected through the questionnaire were analyzed in percentage. This is to describe the factors influencing the ability of the students to use gerund and infinitive. 
RESULTS AND DISCUSSION

Data analysis of the objective of the research was test and questionnaire. The objective test was actually used to measure the students' ability to use
English Gerund and Infinitive, while the questionnaire was used to identify the factors affecting the students to learn English Gerund and Infinitive.

\section{Analysis Data of Test}

Tabel 1

Table of Gerund Score

The Score of Gerund

\begin{tabular}{lll}
\hline $\mathbf{R}$ & $\begin{array}{l}\text { Correct } \\
\text { Answer }\end{array}$ & Score \\
\hline 1 & 1 & 17
\end{tabular}

24

$3 \quad 3$

43

53

$\begin{array}{ll}6 & 4\end{array}$

75

84

95

$10 \quad 2$

114

$12 \quad 2$

132

144

152

$16 \quad 4$

$17 \quad 2$

$18 \quad 5$

$19 \quad 6$

$20 \quad 2$

214

225

$23 \quad 4$

$24 \quad 4$

252

$26 \quad 3$

$27 \quad 3$

$28 \quad 1$

$29 \quad 5$

303
67

50

50

50

67

83

67

83

33

67

33

33

67

33

67

33

83

100

33

67

83

67

67

33

50

50

17

83

50
Table of Infinitive Score

The Score of Infinitive

\begin{tabular}{|c|c|c|}
\hline $\mathbf{R}$ & $\begin{array}{l}\text { Correct } \\
\text { Answer }\end{array}$ & Score \\
\hline 1 & 6 & 67 \\
\hline 2 & 4 & 44 \\
\hline 3 & 7 & 78 \\
\hline 4 & 4 & 44 \\
\hline 5 & 4 & 44 \\
\hline 6 & 4 & 44 \\
\hline 7 & 4 & 44 \\
\hline 8 & 4 & 44 \\
\hline 9 & 7 & 78 \\
\hline 10 & 4 & 44 \\
\hline 11 & 4 & 44 \\
\hline 12 & 6 & 67 \\
\hline 13 & 8 & 89 \\
\hline 14 & 7 & 78 \\
\hline 15 & 6 & 67 \\
\hline 16 & 4 & 44 \\
\hline 17 & 3 & 33 \\
\hline 18 & 8 & 89 \\
\hline 19 & 9 & 100 \\
\hline 20 & 5 & 56 \\
\hline 21 & 5 & 56 \\
\hline 22 & 7 & 78 \\
\hline 23 & 6 & 67 \\
\hline 24 & 2 & 22 \\
\hline 25 & 4 & 44 \\
\hline 26 & 4 & 44 \\
\hline 27 & 6 & 67 \\
\hline 28 & 6 & 67 \\
\hline 29 & 7 & 78 \\
\hline 30 & 6 & 67 \\
\hline
\end{tabular}




\begin{tabular}{lll}
31 & 1 & 17 \\
32 & 4 & 67 \\
33 & 1 & 17 \\
34 & 4 & 67 \\
35 & 3 & 50 \\
36 & 1 & 17 \\
37 & 0 & 0 \\
38 & 3 & 50 \\
39 & 5 & 83 \\
40 & 0 & 0 \\
41 & 2 & 33 \\
42 & 2 & 33 \\
43 & 3 & 50 \\
44 & 2 & 33 \\
45 & 2 & 33 \\
46 & 1 & 17 \\
47 & 2 & 33 \\
48 & 0 & 0 \\
49 & 4 & 67 \\
50 & 5 & 83 \\
51 & 6 & 100 \\
52 & 0 & 0 \\
53 & 0 & 0 \\
54 & 3 & 50 \\
55 & 3 & 50 \\
\hline & Average & 47.88 \\
\hline & &
\end{tabular}

a. The mean score of gerund is 47.88 . It means that in poor classification level.

\begin{tabular}{lll}
31 & 6 & 67 \\
32 & 8 & 89 \\
33 & 1 & 11 \\
34 & 5 & 56 \\
35 & 5 & 56 \\
36 & 6 & 67 \\
37 & 5 & 56 \\
38 & 7 & 78 \\
39 & 6 & 67 \\
40 & 4 & 44 \\
41 & 4 & 44 \\
42 & 6 & 67 \\
43 & 4 & 44 \\
44 & 4 & 44 \\
45 & 5 & 56 \\
46 & 4 & 44 \\
47 & 6 & 67 \\
48 & 5 & 56 \\
49 & 7 & 78 \\
50 & 5 & 56 \\
51 & 5 & 56 \\
52 & 9 & 100 \\
53 & 4 & 44 \\
54 & 6 & 67 \\
55 & 6 & 67 \\
\hline & Average & 59.39 \\
\hline & &
\end{tabular}

b. The mean score of infinitive is 59.39. It means that in fair classification level.

Table 2

Frequency of Gerund and Infinitive

\begin{tabular}{lllll}
\hline \multicolumn{5}{c}{ Frequency } \\
\multicolumn{1}{c}{ Range } & Gerund & \multicolumn{1}{c}{$(\boldsymbol{\%})$} & Infinitive & \multicolumn{1}{c}{$(\boldsymbol{\%})$} \\
\hline 96-100 (Excellent) & 2 & 3.64 & 2 & 3.64 \\
86-95 (Very Good) & 0 & 0 & 3 & 5.45 \\
$76-85$ (Good) & 7 & 12.73 & 7 & 12.73 \\
66-75 (Fairly Good) & 12 & 21.82 & 14 & 25.45 \\
56-65 (Fair) & 0 & 0 & 0 & 0 \\
46-55 (Poor) & 11 & 20 & 9 & 16.36 \\
$0-45$ (Very Poor) & 23 & 41.82 & 20 & 36.36 \\
\hline
\end{tabular}




\begin{tabular}{lllll}
\hline Total & 55 & 100 & 55 & 100 \\
\hline
\end{tabular}

By seeing the table frequency above, the gerund test score on excellent range is $3.64 \%$ ( 2 out of 55 ), the gerund test score on good range is $12.73 \%$ ( 7 out of 55), the gerund test score on fairly good range is $21.82 \%$ (12 out of 55), the gerund test score on poor range is $20 \%$ (11 out of 55), and the gerund test score on very poor range is $41.82 \%$ ( 23 out of 55). Meanwhile, the infinitive test score on excellent range is $3.64 \%$ ( 2 out of 55 ), the infinitive test score on very good range is $5.45 \%$ (3 out of 55), the infinitive test score on good range is $12.73 \%$ (7 out of 55), the infinitive test score on fairly good range is $25.45 \%$ (14 out of 55), the infinitive test score on poor range is $16.36 \%$ ( 9 out of 55), and the infinitive test score on very poor range is $36.36 \%$ (20 out of 55).

On gerund test score, the highest percent rate is on very poor range that is $41.82 \%$ ( 23 out of 55 ), while the excellent range is only $3.64 \%$ ( 2 out of $55)$. Based on the table above the poor and very poor range level is $61.82 \%$ (34 out 55) of the students. In other words, it can be said that more than half respondents were still in low understanding of gerund.

On infinitive test score, the highest percent range is on very poor range that is $36.36 \%$ ( 20 out of 55 ), while the excellent range is only $3.64 \%$ ( 2 out of 55). Based on the table above the poor and very poor range level is $52.72 \%$ (29 out of 55) of the students. In other words, it can be said that more than half respondents were still in low understanding of infinitive.

\section{Analysis Data of Questionnaire}

Table 3

Analysis of Questionnaire on Gerund and Infinitive

\begin{tabular}{lllllrcrrr}
\hline \multicolumn{1}{c}{ Q } & \multicolumn{1}{c}{ Average } & \multicolumn{4}{c}{$(\boldsymbol{\%})$} \\
& $\mathbf{a}$ & $\mathbf{b}$ & $\mathbf{c}$ & $\mathbf{d}$ & $\mathbf{a}$ & $\mathbf{b}$ & $\mathbf{c}$ & $\mathbf{d}$ \\
\hline 1 & 1 & 27 & 26 & 1 & 1.82 & 49.09 & 47.27 & 1.82 \\
2 & 31 & 14 & 10 & 0 & 56.36 & 25.45 & 18.18 & 0.00 \\
3 & 37 & 18 & 0 & 0 & 67.27 & 32.73 & 0.00 & 0.00 \\
4 & 26 & 25 & 3 & 1 & 47.27 & 45.45 & 5.45 & 1.82 \\
5 & 41 & 11 & 3 & 0 & 74.55 & 20.00 & 5.45 & 0.00 \\
6 & 9 & 28 & 12 & 6 & 16.36 & 50.91 & 21.82 & 10.91 \\
7 & 9 & 36 & 10 & 0 & 16.36 & 65.45 & 18.18 & 0.00 \\
8 & 16 & 27 & 11 & 1 & 29.09 & 49.09 & 20.00 & 1.82 \\
9 & 23 & 18 & 8 & 6 & 41.82 & 32.73 & 14.55 & 10.91 \\
10 & 37 & 13 & 5 & 0 & 67.27 & 23.64 & 9.09 & 0.00 \\
11 & 24 & 29 & 2 & 0 & 43.64 & 52.73 & 3.64 & 0.00 \\
12 & 4 & 26 & 25 & 0 & 7.27 & 47.27 & 45.45 & 0.00 \\
13 & 2 & 14 & 35 & 4 & 3.64 & 25.45 & 63.64 & 7.27 \\
14 & 2 & 17 & 33 & 3 & 3.64 & 30.91 & 60.00 & 5.45 \\
15 & 9 & 16 & 27 & 3 & 16.36 & 29.09 & 49.09 & 5.45 \\
\hline
\end{tabular}




\section{Questionnaire item no.1}

It discusses about the students' opinion in learning English. The data shows that $49.09 \%$ of the students (27 out of 55) stated that it was easy to learn English, $47.27 \%$ of the students (26 out of 55) said that it was difficult to learn English, $1.82 \%$ of the student (1 out of 55) said it was very easy to learn English, and $1.82 \%$ of the student ( 1 out of 55) said that it was very difficult to learn English.

\section{Questionnaire item no.2}

It discusses about how much the students interested in learning English Structure. The data result is that $56.36 \%$ of the students ( 31 out of 55) said that they were interested in learning English Structure, $25.45 \%$ of the students (14 out of 55) said that they were less interested in learning English Structure, $18.18 \%$ of the students (10 out 50) said that they were very interested in learning English Structure.

\section{Questionnaire item no.3}

It discusses about how the students got the assignment from their lecturer. The data represents that $67.27 \%$ of the students (37 out of 55) said that they always got assignment from their lecturer, and $32.73 \%$ of the students (18 out of 55) said that they often got the assignment from their lecturer.

\section{Questionnaire item no.4}

It discusses about the students' opinion in learning gerund and infinitive. The data shows that $47.27 \%$ of the students (26 out of 55) said that it was very important to learn about gerund and infinitive, $45.45 \%$ of the students (25 out of 55) said that it was important to learn about gerund and infinitive, $5.45 \%$ of the students (3 out of 55) said that it was less important to learn about gerund and infinitive, and $1.82 \%$ of the students (1 out of 55) said that it was not important to learn about gerund and infinitive.

\section{Questionnaire item no.5}

It discusses about the students' activities during English Structure lesson. The data shows that $74.55 \%$ of the students (41 out of 55) said that they were listening, paying attention, and writing down during English Structure lesson, $20 \%$ of the students (11 out of 55) said that they were listening and taking note during English Structure lesson, and 5.45\% of the students said that they were only listening during English Structure lesson.

\section{Questionnaire item no.6}

It discusses about the students' asking the question to the lecturer if they didn't understand to the material explanation. The data shows that $50.91 \%$ of the students ( 28 out of 55) said that they were seldom asking the question to the lecturer if they didn't understand to the material explanation, $21.82 \%$ of the students (12 out of 55) said that they were very seldom asking the question to the lecturer if they didn't understand to the material explanation, $16.36 \%$ of the students ( 9 out of 55) said that they were always asking the question to the lecturer if they didn't understand to the material explanation, and $10.91 \%$ of the students (6 out of 55) said that they were never asking the question to the lecturer if they didn't understand to the material explanation.

\section{Questionnaire item no.7}

It discusses about the students' opinion about their understanding on 
English Structure. The data shows that $65.45 \%$ of the students ( 36 out of 55 ) said that they did not very quickly understand on English Structure lesson, $18.18 \%$ of the students (10 out of 55) said that they less understood on English Structure lesson, and $16.36 \%$ of the students (9 out of 55) said that they quickly understand on English Structure lesson.

\section{Questionnaire item no.8}

It discusses about the students' frequency on their practicing in gerund and infinitive exercises. The data shows that $49.09 \%$ of the students (27 out of 55) said that they seldom practiced in gerund and infinitive exercises, $29.09 \%$ of the students (16 out of 55) said that they always practiced in gerund and infinitive exercises, $20 \%$ of the students (11 out of 55) said that they less practiced in gerund and infinitive exercises, and $1.82 \%$ of the students (1 out of 55) said that he never practiced in gerund and infinitive exercises.

\section{Questionnaire item no.9}

It discusses about the serve about gerund and infinitive book in campus library. The data shows that $41.82 \%$ of the students ( 23 out of 55) said that the book about gerund and infinitive was very complete in campus library, $32.73 \%$ of the students (18 out of 55) said that the book about gerund and infinitive was seldom in campus library, $14.55 \%$ of the students (8 out of 55) said that the book about gerund and infinitive was less complete in campus library, and $10.91 \%$ of the students (6 out of 55) the book about gerund and infinitive did not complete in campus library.

\section{Questionnaire item no.10}

It discusses about the lecturer's reminding toward the students about studying gerund and infinitive. The data shows that $67.27 \%$ of the students (37 out of 55) said that the lecturer always reminded the students about studying gerund and infinitive, $23.64 \%$ of the students (13 out of 55) said that the lecturer often reminded the students about studying gerund and infinitive, $9.09 \%$ of the students (5 out of 55) said that the lecturer seldom reminded the students about studying gerund and infinitive.

\section{Questionnaire item no.11}

It discusses about the book used in the classroom on learning gerund and infinitive. The data shows that $52.73 \%$ of the students (29 out of 55) said that the book used in the classroom on learning gerund and infinitive was complete enough, $43.64 \%$ of the students (24 out of 55) said that the book used in the classroom on learning gerund and infinitive was most complete, $3.64 \%$ of the students (2 out of 55) said that the book used in the classroom on learning gerund and infinitive was less complete.

\section{Questionnaire item no.12}

It discusses about students' opinion on learning gerund and infinitive. The data shows that $47.27 \%$ of the students (26 out of 55) said that it was easy to learn gerund and infinitive, $45.45 \%$ of the students ( 25 out of 55 ) said that it was difficult to learn gerund and infinitive, $7.27 \%$ of the students (4 out of 55) said that it was very easy to learn gerund and infinitive.

\section{Questionnaire item no.13}

It discusses about how much times the students read their book about gerund 
and infinitive. The data shows that $63.64 \%$ of the students (35 out of 55) said that they seldom read their book about gerund and infinitive, $25.45 \%$ of the students (14 out of 55) said that they often read their book about gerund and infinitive, $7.27 \%$ of the students (4 out of 55) said that they never read their book about gerund and infinitive, and $3.64 \%$ of the students (2 out of 55) said that they always read their book about gerund and infinitive.

\section{Questionnaire item no.14}

It discusses about the students' opinion on their mistake on doing gerund and infinitive exercises. The data shows that $60 \%$ of the students (33 out of 55) said that they seldom practiced to do whether gerund or infinitive exercises, $30.91 \%$ of the students (17 out of 55) said that they could not differentiate well about gerund and infinitive, $5.45 \%$ of the students (3 out of 55) said that they never practiced to do whether gerund or infinitive exercises, and $3.64 \%$ of the students (2 out of 55) said that they it was very difficult to do whether gerund or infinitive exercises.

\section{Questionnaire item no.15}

It discusses about how much times the students' learning from their corrected paperback. The data shows that $49.09 \%$ of the students ( 27 out of 55) said that they seldom learned from their corrected paperback, $29.09 \%$ of the students (16 out of 55) said that they often learned from their corrected paperback, $16.36 \%$ of the students (9 out of 55) said that they always learned from their corrected paperback, and $5.45 \%$ of the students (3 out of 55) said that they never learned from their corrected paperback.

On the questionnaire result, there are several factors that influence the students' test result they are as follows; 1) it was easy to learn English, 2) they were interested in learning English Structure, 3) they always got assignment from their lecturer, 4) it was very important to learn about gerund and infinitive, 5) they were listening, paying attention and writing down during English Structure lesson, 6) they seldom asked the question to the lecturer if they didn't understand to the material explanation, 7) they did not very quickly understand on English Structure lesson, 8 ) they seldom practiced in gerund and infinitive exercises, 9) the book about gerund and infinitive was very complete in campus library, 10) the lecturer always reminded the students about studying gerund and infinitive, 11) the book used in the classroom on learning gerund and infinitive was complete enough, 12) it was easy to learn gerund and infinitive, 13) they seldom read their book about gerund and infinitive, 14) they seldom practiced to do whether gerund or infinitive exercises, 15) they seldom learned from their corrected paperback.

The respondents stated easy to learn English, they interested in learning English Structure, they always got assignments from their lecturer, they thought that it was very important to learn about gerund and infinitive, they were listening, paying attention and writing down during English Structure lesson, the book about gerund and infinitive was very complete in campus library, the lecturer always reminded the students about studying gerund and infinitive, the book used in the classroom on learning gerund and infinitive was complete enough, they thought that it was easy to learn gerund and infinitive, however, the respondents seldom asked 
the question to the lecturer if they didn't understand to the material explanation, they did not very quickly understand on English Structure lesson, they seldom practiced in gerund and infinitive exercises, they seldom read their book about gerund and infinitive, they seldom practiced to do whether gerund or infinitive exercises, and they seldom learned from their corrected paperback.

This study compares to Arham (2016) that his study about the ability and factors affecting the students to use english gerund resulted the ability of the second year students of Senior High School Tamalatea Makassar in using English gerund was very poor because the mean score was 4,5 . It meant that they were not successful in learning English Structure especially English gerund, and the factors were they were lack of motivation, low frequency of practice or exercise, lack of literature and the teacher's method in teaching were not very effective.

Different to (Kitikanan, 2016) her study resulted that it was found that Thai students had low proficiency on both types of verbal complements. It also showed that their to infinitive knowledge was lower than their gerund knowledge. Her study was different from other studies in that it directly elicited factors from second language learners themselves, rather than predicting factors from the answers of learners, and otherwise solely relying on the rather subjective analysis of the researcher.

\section{CONCLUSION}

The ability of the students in second year of Indraprasta PGRI University on mastering the using of gerund is on very poor range that is $41.82 \%$ (23 out of 55 ), in other words, it can be said that more than half respondents were still in low understanding of gerund, while mastering the using to-infinitive form is on very poor range that is $36.36 \%$ (20 out of 55).

The factors affecting of the students in second year of Indraprasta PGRI University on mastering the using of gerund and infinitive form are they seldom asked the question to the lecturer if they didn't understand to the material explanation, they did not very quickly understand on English Structure lesson, they seldom practiced in gerund and infinitive exercises, they seldom read their book about gerund and infinitive, they seldom practiced to do whether gerund or infinitive exercises, and they seldom learned from their corrected paperback.

This study is still very far from being perfect article, and the result of this study does not represent all the students in Indraprasta PGRI University especially on English education program. However, the result of this study may motivate the lecturer especially on teaching English Structure to find other more ways to improve the students' ability on its. Beside of that the linier study also can be researched in other aspect such as tenses, clauses, phrases, genre of sentences, etc.

\section{REFERENCES}

Arham, R. (2016). The ability and factors affecting the students to use english gerund. International Journal of Scientific \& Technology Research Volume, 5(05).

Azar, B. S. (2009). Understanding and Using English Grammar. Fourth Edition. New York: Pearson Education Ltd.

Dudeney, G., \& Hockly, N. (2010). Learning English as a Foreign Language for Dummies. West Sussex: John Wiley \& Sons, Ltd. Harmer, J. (1997). How To Teach English. London: Longman 
Publisher.

Kitikanan, P. (2016). Kitikanan, Patchanok. (2011). The Thai EFL students' ability to use the gerund and to-Infinitive. The International Journal of the Humanities . 9( 2 ). 279-290 ., (September). https://doi.org/10.18848/14479508/CGP/v09i02/43131

Seely, J. (2007). Grammar for Teachers.
Tiverton: Oxpecker.

Thornbury, S. (2002). How To Teach Grammar. (J. Harmer, Ed.). Oxfordshire: Bluestone Press.

Ur, P. (2007). Grammar Practice Activities: A Practical Guide for Teachers. Cambridge: Cambridge University Press. 